\title{
THE BINDING OF ALDOSTERONE TO PLASMA PROTEINS IN NORMAL, PREGNANT, AND STEROID-TREATED WOMEN *
}

\author{
BY CLAUDE J. MEYER, † DONALD S. I.AYNE, JAMES F. TAIT \\ AND GREGORY PINCUS
}

(From The Worcester Foundation for Experimental Biology, Shrezusbury, Mass.)

(Submitted for publication February 27, 1961 ; accepted May 12, 1961)

There is now abundant evidence that both cortisol and corticosterone are bound in plasma to a protein with high affinity and low capacity (probably an $\alpha$-globulin termed transcortin) as well as to albumin (1-10). It has also been shown that either the concentrations of transcortin or its affinity for cortisol is increased in pregnancy and after estrogen treatment $(4,10)$, although one group (10) has not found increased binding of tracer amounts of cortisol in pregnancy. Preliminary studies by Mills, Chen and Bartter $(7,8)$ indicated that aldosterone is bound to proteins other than albumin to a much lesser extent than is cortisol. Sandberg, Slaunwhite and Carter (9) reported an appreciable binding of aldosterone in diluted plasma dialyzed against albumin at $4^{\circ} \mathrm{C}$. The aldosterone was readily displaced from the binding protein by the addition of cortisol, while cortisol binding under similar conditions was not significantly reduced by the addition of physiological amounts of aldosterone (9). During the preparation of this manuscript Daughaday, Holloszy and Mariz (10) reported that at $37^{\circ} \mathrm{C}$ they could not demonstrate any binding of aldosterone to proteins other than albumin in the plasma of normal women or in that of pregnant subjects and women treated with estrogen, but they found appreciable binding of aldosterone to such a protein in normal plasma at $4^{\circ} \mathrm{C}$. The present paper gives detailed data on the binding of aldosterone in normal plasma, obtained by a microdialysis technique with $7-\mathrm{H}^{3}$ aldosterone of high specific activity $(20 \mu \mathrm{c}$ per $\mu \mathrm{g})$. Plasma from pregnant subjects and from

* Supported in part by Grants A-3179, A-3598 and A-3490 from the United States Public Health Service, by Institutional Grant 1 from the American Cancer Society (Massachusetts Division) Inc., by a grant from Mrs. Stanley McCormick, and by United States Atomic Energy Grant AT (30-1) -918.

$\dagger$ Trainee in the Program for Steroid Biochemistry supported by Grant 5001 of the National Cancer Institute. women treated with Enovid ${ }^{1}$ was also studied. The results, in agreement with those of previous workers (7-10), indicate that the binding of aldosterone to a protein other than albumin (henceforward termed relative binding) is much less than in the case of cortisol. They provide evidence, however, that there is significant binding to such a protein or proteins in both normal and pregnant subjects at both $37^{\circ}$ and $4^{\circ} \mathrm{C}$, and that this relative binding is considerably increased by treatment with Enovid.

\section{MATERIALS AND METHODS}

Suljects. The patients treated with Enovid were chronic female schizophrenics in an open ward at the Worcester State Hospital. Each received $10 \mathrm{mg}$ per day of the oral medication for 24 days, followed by 6 days without treatment. Each patient had completed at least two such cycles before being used in this study. Blood samples were taken between Days 18 and 22 of treatment. Some of the control subjects were also inmates of this ward while others were normal volunteers. No differences in plasma-binding capacity for cortisol, or in any other factors applicable to this study were observed between the volunteers and the control inmates. Blood was drawn from the controls between Days 18 and 22 of the menstrual cycle. Plasma from women in the third trimester of pregnancy was kindly made available by $\mathrm{Dr}$. Brian Little of Boston City Hospital. All blood samples were drawn into heparinized tubes and the plasma separated immediately by centrifugation. When necessary, plasma was stored at $-10^{\circ} \mathrm{C}$ before use. No change in binding capacity for either cortisol or aldosterone was observed after storage for up to 3 weeks. Penicillin G (10,000 units) (Eli Lilly) was added to all plasmas. In agreement with Slaunwhite and Sandberg (3), this did not affect binding values.

Since most of the dialyses were carried out at $37^{\circ} \mathrm{C}$ for 22 hours the effects of penicillin-resistant bacterial contamination are an important consideration. However, the concentrations of radioactivity followed a smooth curve

\footnotetext{
1 A mixture of 98 per cent norethynodrel, $17 \alpha$-ethynyl$17 \beta$-hydroxy-5(10)-estrene-3-one and 2 per cent of the 3 -methyl ether of $17 \alpha$-ethynyl-estra-1:3:5(10)-triene-3, $17 \beta$-diol.
} 
with time and reached a plateau from 18 to 22 hours. It seems unlikely that the dialytic process and bacterial breakdown of the complex would be in exact equilibrium during this time, although the decrease in concentration in the inner chamber after 22 hours may be due to bacterial action. There was also no evidence of conversion of steroids during the dialysis, and the results for cortisol binding agree with those determined by ultrafiltration methods $(7,8)$ which can be carried out in a shorter time.

Measurement of binding or relative binding. Three $\mathrm{ml}$ of plasma or $1 \mathrm{ml}$ of plasma diluted to $3 \mathrm{ml}$ with 0.9 per cent saline, together with two Teflon-coated ball bearings, was placed in the inner chamber of a dialysis cell as described by Kalant (11). A Cellophane membrane was tied over the inner portion of the cell with cotton thread. The Cellophane was stored in distilled water and a new membrane was used for each determination. Twenty $\mathrm{ml}$ of 0.9 per cent saline or of a solution of human serum albumin in saline was placed in the outside chamber, and radioactive or inert steroids dissolved in $1.0 \mathrm{ml}$ of saline were added to this chamber. The $7-\mathrm{H}^{3}$-aldosterone (20 $\mu \mathrm{c}$ per $\mu \mathrm{g}$ ) or $7-\mathrm{H}^{3}$-cortisol (28 $\mu \mathrm{c}$ per $\mu \mathrm{g}$ ) used was prepared and tested for radiochemical purity as previously described for $16-\mathrm{H}^{3}$ steroids (12). $\mathrm{H}^{3}$-estrone was donated by Dr. Marcel Gut; this steroid was purified by partition chromatography on Celite and tested by paper chromatography. All isotopic steroids were at least 98 per cent pure according to these criteria. The albumin used routinely was supplied by the Commonwealth of Massachusetts, Department of Public Health, Biologic Laboratories ${ }^{2}$ in bottles containing $25 \mathrm{~g}$ in $100 \mathrm{ml}$ solution, stabilized with $0.02 \mathrm{M}$ sodium caprylate and $0.02 \mathrm{M}$ sodium acetyltryptophanate. This albumin was 98 per cent pure as judged by paper electrophoresis. Before use the albumin solution was placed in a Cellophane bag and dialyzed on a mechanical shaker for 24 hours against a continuously replenished solution of physiological saline. This procedure removes a Porter-Silber chromogen which was present in the albumin. A few experiments (Table IV) were carried out with albumin that was 100 per cent pure electrophoretically. The difference in the results for the 100 and 98 per cent pure albumin were not great enough to affect the interpretation of the results, although they should be noted. In some cases the albumin content of individual plasmas was determined by the color produced with 2-(4'-hydroxybenzeneazo) benzoic acid (13), pure human serum albumin serving as standard.

Dialysis was performed for 22 hours at $37^{\circ}$ or for 36 hours at $4^{\circ} \mathrm{C}$, the cell being continuously agitated on a mechanical shaker. These times were chosen because preliminary experiments with normal plasma showed that the percentage of aldosterone (and of cortisol) bound at $37^{\circ} \mathrm{C}$ reached a constant maximum between 18 and 22 hours. After this the amount bound decreased, probably due to breakdown of the complex. At $4^{\circ} \mathrm{C}$ the rise to maximal binding was obtained after 36 hours. The percentage bound then remained constant for an indefinite

${ }^{2} \mathrm{We}$ are indebted to $\mathrm{Mr}$. Lewis $\mathrm{H}$. Larsen for making the albumin available and for advice on its purity. time. This constant concentration after 36 hours at $4^{\circ} \mathrm{C}$ was also found when steroid was added to albumin and dialyzed against saline.

After equilibration an aliquot of $0.6 \mathrm{ml}$ of the material in each of the inner and outer chambers was placed in a counting vial with $6 \mathrm{ml}$ of ethanol, and $10 \mathrm{ml}$ of scintillation fluid which contained $4 \mathrm{~g}$ diphenyloxazole and 100 mg 1,4-bis-2-(5-phenyloxolyl) benzene per $\mathrm{L}$ toluene (14) was added. The vials were counted in the Packard Tricarb liquid scintillation spectrometer for the time necessary to obtain at least 5,000 counts per vial, and the percentage binding or relative binding of the added steroid was determined from the formula:

$$
\% \text { bound }=\left(1-\frac{C_{O}}{C_{I}}\right) 100
$$

where $C_{I}$ and $C_{o}$ were, respectively, the counts in the 0.6$\mathrm{ml}$ aliquots from the inner and outer chambers. Since aldosterone (and also cortisol) were shown by paper chromatography to be unchanged after dialysis, it was considered valid to count the aliquots directly without prior purification of the radioactive steroid. No individual quenching correction was used in counting the samples, since this was found in several preliminary experiments to be the same for all the aqueous phases used.

Errors of the method. The measurement of binding or relative binding by the ratio of the counts in equal aliquots from the inner and outer dialysis cells has the advantage that the result is independent of volume changes between the chambers except as a second-order effect, since in the above formula only concentration terms are involved. The change of volume could affect the binding estimates insofar as the protein concentration would alter. However, in certain experiments the volume changes were measured and in all cases found to be less than 10 per cent. This alteration in protein concentration would not be expected to affect the interpretation of the results, judged by the control experiments to be described later.

The method is subject to errors from the counting procedure and from any leakage that might occur around the dialysis membrane. Consistently high binding figures ( $>90$ per cent) in some experiments indicated that leakage was not important routinely. Consistent recoveries of 95 per cent of the radioactivity added indicated that binding of the radioactive steroid to the membrane was not an important factor. In any case, such binding would not affect the ratio of the counts in the two chambers, although it could theoretically be important if aliquots were continuously withdrawn for counting. For any given determination of binding or relative binding the coefficient of variation $(\sigma)$ may be expressed as

$$
\sigma=\frac{100-\% \text { binding }}{100} \times K
$$

where $K$ is the coefficient of variation in the determination of $C_{o} / C_{I}$ which is assumed to be constant for the high counting samples used in this work. In several experiments where triplicate determinations were carried out on the same plasma which bound 10 per cent of the $\mathrm{H}^{3}$-aldo- 
TABLE I

Per cent relative binding of $7-H^{3}$-aldosterone to human plasma at $37^{\circ} \mathrm{C}$; effect of different amounts of steroid

\begin{tabular}{|c|c|c|c|}
\hline $\begin{array}{l}\text { Inner chamber } \\
\text { Plasma, } m l \\
\text { Outer chamber } \\
\text { Albumin, \% } \\
\text { 7-H }{ }^{3} \text {-aldosterone, } m \mu g \\
\text { Inert } d \text {-aldosterone, } m \mu g\end{array}$ & $\begin{array}{c}3 \\
4.3 \\
0.2\end{array}$ & $\begin{array}{r}3 \\
4.3 \\
0.2 \\
10.0\end{array}$ & $\begin{array}{r}3 \\
\\
4.3 \\
0.2 \\
3,000\end{array}$ \\
\hline $\begin{array}{lr}\text { Control } & \text { I } \\
\text { Subjects } & \text { II } \\
& \text { III }\end{array}$ & $\begin{array}{r}13 \\
3 \\
21\end{array}$ & $\begin{array}{l}11 \\
18 \\
21\end{array}$ & $\begin{array}{r}-9 \\
13 \\
19\end{array}$ \\
\hline Mean & 12 & 17 & 8 \\
\hline $\begin{array}{l}\text { Enovid-treated } \\
\text { subject }\end{array}$ & 38 & 39 & 31 \\
\hline
\end{tabular}

sterone, the coefficient of variation of the mean value was estimated statistically at about 6 per cent. Thus :

$$
K=\frac{100 \times 6}{90}=6.6
$$

By using this value of $K, \sigma$ for other experiments may be calculated. Hence for triplicate determinations giving mean values for percentage binding of $10,20,30$, and 50 , the true result will be, respectively, $10 \pm 6,20 \pm 5.3$, $30 \pm 4.6$, and $50 \pm 3.3$. In the present paper all values quoted are the means of triplicate determinations, and a result of 10 per cent or greater is regarded as significant binding of the radioactive steroid for an individual plasma sample.

\section{RESULTS}

Influence of quantity of steroid on per cent binding. Table I shows the per cent relative binding of $7-\mathrm{H}^{3}$-aldosterone in plasma after dialysis against 4.3 per cent albumin. This concentration of albumin was approximately equal to that in normal plasma as judged by colorimetric determinations on plasma by the method of Rutstein, Ingenito and Reynolds (13) ; 0.2, 10.2, and 3,000.2 $\mathrm{m} \mu \mathrm{g}$ aldosterone were added to the dialysis cell together with plasmas from three normal subjects and one plasma from an Enovid-treated patient. In all cases, the difference in per cent relative binding when $0.2,10.2$, and $3,000.2 \mathrm{~m} \mu \mathrm{g}$ of steroid were added was negligible. Also; four normal plasmas with $1.0 \mathrm{~m} \mu \mathrm{g} 7-\mathrm{H}^{3}$-aldosterone (Table II) and three with $3.0 \mathrm{~m} \mu \mathrm{g}$ (Table III) were dialyzed against 5 per cent albumin. No difference in binding was observed and therefore 1.0 $\mathrm{m} \mu \mathrm{g}$ or, more conveniently, $3.0 \mathrm{~m} \mu \mathrm{g}$ of radioactive aldosterone was used routinely in order to reduce the counting time necessary for individual sam-

TABLE II

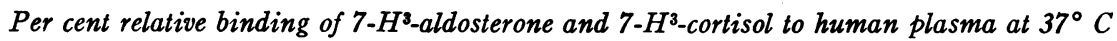

\begin{tabular}{|c|c|c|c|c|c|c|}
\hline \multirow{3}{*}{$\begin{array}{l}\text { Inner chamber } \\
\text { Plasma, } m l \\
\text { Saline, } m l \\
\text { Outer chamber } \\
\text { Albumin, \% } \\
\text { 7-H-aldosterone, } m \mu g \\
\text { Inert } d \text {-aldosterone, } m \mu g\end{array}$} & & \multicolumn{4}{|c|}{ Aldosterone } & \multirow{3}{*}{$\begin{array}{c}\text { Cortisol } \\
1 \\
2 \\
1.6 \\
5 \\
7-\mathrm{H}^{3} \text {-cortisel }\end{array}$} \\
\hline & & $\begin{array}{l}1 \\
2\end{array}$ & $\begin{array}{l}1 \\
2\end{array}$ & 1 & 3 & \\
\hline & & $\begin{array}{l}1.6 \\
1.0\end{array}$ & $\begin{array}{r}1.6 \\
1.0 \\
3,000\end{array}$ & $\begin{array}{l}5 \\
1.0\end{array}$ & $\begin{array}{l}5 \\
1.0\end{array}$ & \\
\hline \multirow[t]{2}{*}{ Control subjects } & $\begin{array}{l}\text { A } \\
\text { B } \\
\text { C } \\
\text { D }\end{array}$ & $\begin{array}{r}17 \\
-11 \\
-\quad 9 \\
17\end{array}$ & $\begin{array}{r}15 \\
7 \\
13 \\
13\end{array}$ & $\begin{array}{l}6 \\
1 \\
1 \\
5\end{array}$ & $\begin{array}{r}8 \\
23 \\
16 \\
14\end{array}$ & $\begin{array}{l}74 \\
76 \\
71 \\
77\end{array}$ \\
\hline & Mean & 8.5 & 12 & 3 & 15 & 74 \\
\hline \multirow[t]{2}{*}{$\begin{array}{l}\text { Enovid-treated } \\
\text { patients }\end{array}$} & $\begin{array}{l}E \\
F \\
G \\
H\end{array}$ & $\begin{array}{l}11 \\
30 \\
40 \\
42\end{array}$ & $\begin{array}{l}17 \\
29 \\
33 \\
37\end{array}$ & $\begin{array}{l}14 \\
16 \\
19 \\
32\end{array}$ & $\begin{array}{l}26 \\
39 \\
46 \\
47\end{array}$ & $\begin{array}{l}90 \\
92 \\
95 \\
95\end{array}$ \\
\hline & Mean & 31 & 29 & 20 & 40 & 93 \\
\hline \multirow[t]{2}{*}{ Pregnant subjects } & $\begin{array}{l}\mathrm{J} \\
\mathrm{K} \\
\mathrm{L} \\
\mathbf{M} \\
\mathrm{N}\end{array}$ & $\begin{array}{r}0 \\
17 \\
17 \\
12 \\
6\end{array}$ & $\begin{array}{r}4 \\
13 \\
13\end{array}$ & $\begin{array}{r}-2 \\
2 \\
-16\end{array}$ & $\begin{array}{l}13 \\
15 \\
21 \\
22 \\
15\end{array}$ & $\begin{array}{l}81 \\
80 \\
87 \\
85 \\
83\end{array}$ \\
\hline & Mean & 10 & 10 & -5 & 17 & 83 \\
\hline $\begin{array}{l}\text { Subject in early } \\
\text { pregnancy }\end{array}$ & $\mathrm{P}$ & 14 & 10 & & 13 & 79 \\
\hline
\end{tabular}


ples. Although the quantities added routinely are therefore 0.033 or $0.1 \mu \mathrm{g}$ per $100 \mathrm{ml}$ of plasma (giving much lower concentrations in the chambers after dialysis) these would still be lower than the normal plasma concentration of aldosterone or that attained in subjects on a low-salt diet (15), and the results above indicate that the per cent binding will be the same as if only negligible amounts of radioactive aldosterone had been added.

Relative binding of aldosterone in normal plasma. The results in Table II show that the binding of aldosterone to normal plasma diluted with saline and dialyzed against 1.6 per cent albumin is -9 to 17 per cent (mean 8.5) for four subjects, a result which is probably not significantly above zero. The binding of cortisol to the same plasmas under the same conditions was 71 to 77 per cent, which is of the same order as that obtained by Slaunwhite and Sandberg (3) who used a similar technique and the same temperature. Even when undiluted plasma was dialyzed against 5 per cent albumin, the per cent binding of aldosterone was much less than that of cortisol in diluted plasma. These results support the conclusions of previous workers $(7-10)$ that the binding of aldosterone to proteins other than albumin is small compared with that of cortisol.

Altogether seven normal undiluted plasmas (Tables II and III) were dialyzed against 5 per cent albumin at $37^{\circ} \mathrm{C}$ and the per cent binding was $16.4 \pm 2.2$ (SE). No individual value was less than 8 per cent. At $4^{\circ} \mathrm{C}$ the per cent binding of three plasmas was 82, 86, and 75. This increase of binding at low temperature parallels that observed for the binding of cortisol to transcortin (3) and confirms the fact that aldosterone is bound to proteins other than albumin, since the binding of aldosterone to albumin is largely independent of temperature (Table IV), in agreement with the results of Daughaday and co-workers (10).

Colorimetric estimation (13) on several plasmas indicated an albumin content of 4.3 per cent for normal plasma and lower values in pregnant and Enovid-treated subjects. The method was not considered extremely accurate, however, and even though dialysis was performed against 5 per cent albumin, the question arose of whether the values obtained for aldosterone binding could have been caused by a greater concentration of albumin in the inner than the outer chamber. This possibility is illustrated by the insignificant aldosterone relative binding obtained when diluted plasma, the albumin concentration of which was about 1.3 per cent, was dialyzed against 5 per cent albumin (Table II), and by the appreciable binding of aldosterone to albumin dialyzed against saline ( 50 per cent, Table IV), which is of the same order as that of cortisol. It was therefore thought necessary to do other experiments to examine the possible effect of differing albumin concentrations in the two chambers. Estrone has been reported to be bound strongly to albumin and, to a negligible extent, to other proteins (3). Although we have found that when 1 to $3 \mathrm{~m} \mu \mathrm{g}$ of estrone (20 $\mu \mathrm{c}$ per $\mu \mathrm{g}$ ) is added to $3 \mathrm{ml}$ of plasma, binding to other proteins can be appreciable, we have confirmed the high binding of the steroid to albumin (90 per cent, Table IV) under several conditions of dialysis. If the amount of estrone is raised to $10.0 \mu \mathrm{g}$ per $3 \mathrm{ml}$ plasma (initial concentration), the binding to albumin is unchanged (Table IV) while that to other proteins is reduced to very small amounts (Table III). At this concentration estrone can therefore be used as an indicator of albumin binding.

Table III shows results obtained with three plasmas in which the binding capacity for aldosterone and for estrone $(10 \mu \mathrm{g}$ per $3 \mathrm{ml})$ was measured by dialysis against 5 per cent albumin. The per cent binding of aldosterone at $37^{\circ} \mathrm{C}$ was 17,24 , and 13 , and the corresponding values for estrone were $-1,8$, and 4 . The values for per

TABLE III

Per cent relative binding of aldosterone and estrone to plasma of control subjects at $37^{\circ}$ and at $4^{\circ} \mathrm{C}$

\begin{tabular}{|c|c|c|}
\hline Inner chamber & $3 \mathrm{ml}$ Plasma & $3 \mathrm{ml}$ Plasma \\
\hline Outer chamber & $\begin{array}{l}5 \% \text { Albumin } \\
3.0 \mathrm{m \mu g} 7-\mathrm{H}^{3-} \\
\text { aldosterone }\end{array}$ & $\begin{array}{l}5 \% \text { Albumin } \\
5.0 \mathrm{m \mu g} 16-\mathrm{H}^{3} \text {-estrone } \\
10 \mathrm{\mu g} \text { inert estrone }\end{array}$ \\
\hline $37^{\circ}$ & $\begin{array}{l}17 \\
24 \\
13\end{array}$ & $\begin{array}{r}-1 \\
8 \\
4\end{array}$ \\
\hline Mean & 18 & 4 \\
\hline $4^{\circ}$ & $\begin{array}{l}82 \\
86 \\
75\end{array}$ & $\begin{array}{r}-50 \\
-75 \\
-120\end{array}$ \\
\hline Mean & 81 & -82 \\
\hline
\end{tabular}


TABLE IV

Per cent binding of radioactive steroids to albumin*

\begin{tabular}{|c|c|c|c|c|c|}
\hline $\begin{array}{l}\text { Inner chamber } \\
\text { Albumin, \% } \\
\text { Outer chamber }\end{array}$ & $\begin{array}{c}1.6 \\
5 \mathrm{~m} \mu \mathrm{g} 16-\mathrm{H}^{3}- \\
\text { estrone }+10 \mu \mathrm{g} \\
\text { inert estrone } \\
\text { in saline }\end{array}$ & $\begin{array}{c}5 \\
5 \text { m } \mu g \text { 16- } \mathrm{H}^{3}- \\
\text { estrone in } \\
\text { saline }\end{array}$ & $\begin{array}{c}5 \\
5 \mathrm{~m} \mu \mathrm{g} 16-\mathrm{H}^{3}- \\
\text { estrone }+10 \mu \mathrm{g} \\
\text { inert estrone } \\
\text { in saline }\end{array}$ & $\begin{array}{c}5 \\
5 \mathrm{~m} \mu \mathrm{g} \\
\text { 7- } \\
\text { cortisol in } \\
\text { saline }\end{array}$ & $\begin{array}{c}5 \\
5 \mathrm{~m} \mu \mathrm{g} 7-\mathrm{H}^{3}- \\
\text { aldosterone } \\
\text { in saline }\end{array}$ \\
\hline $\begin{array}{r}37^{\circ} \\
4^{\circ}\end{array}$ & $\begin{array}{l}83 \\
90\end{array}$ & $\begin{array}{ll}92 & 93 \dagger \\
93 & 95 \dagger\end{array}$ & 92 & $\begin{array}{ll}48 & 57 \dagger \\
52 & 66 \dagger\end{array}$ & $\begin{array}{ll}40 & 50 \dagger \\
51 & 56 \dagger\end{array}$ \\
\hline
\end{tabular}

* The first figure in each column represents \% binding to the "98\% pure" albumin used throughout these experiments. The second figure, markedt, represents $\%$ binding to a sample of albumin that was $100 \%$ pure as judged by paper electrophoresis.

cent binding of aldosterone at $4^{\circ} \mathrm{C}$ were 82,86 , and 75 , and for estrone $-50,-74$, and -120 . Negative values presumably reflect a greater concentration of albumin in the outer chamber. The increased binding of aldosterone at low temperature would be expected if the protein responsible behaved like transcortin (3), while the negative values for estrone would result from a higher concentration of albumin in the outer chamber, since it has been shown (Table IV) that the binding of estrone to the albumin used in these experiments is increased at low temperature. Because of the high binding of estrone to albumin, such increases could be clearly demonstrated only when dilute solutions of the albumin were dialyzed against saline. However, if albumin solutions of only slightly differing concentration were present in both chambers and the binding were high, then the relative binding could have a high temperature coefficient. Since the binding of aldosterone to albumin is not strongly dependent on temperature (Table IV) (10) the high values of binding found for this hormone at $4^{\circ} \mathrm{C}$ must be due to a protein other than albumin.

Relative binding of aldosterone in plasma of pregnant subjects. In agreement with the results of previous workers (3) the binding of cortisal was found to be elevated in plasmas from five subjects in the last trimester of pregnancy. The value for the plasma of one subject in early pregnancy was increased to a lesser extent. However, the results for aldosterone relative binding (Table II, Figure 1), although significant $(17 \pm 1.7)$, were of the same order as those of the controls $(16.4 \pm 2.2)$ in all these plasmas. Previous workers $(16,17)$ have reported and we have confirmed, that the concentration of albumin is lower in pregnancy plasma than in normal plasma, so that it is most unlikely that the values obtained could be due to binding by albumin. The effect of this lowered albumin concentration in the inner chamber would be to lower the binding found in our experiments, and it is therefore not possible to conclude from the result that there is no increase of aldosterone binding in pregnancy, but any such increase is probably very small.

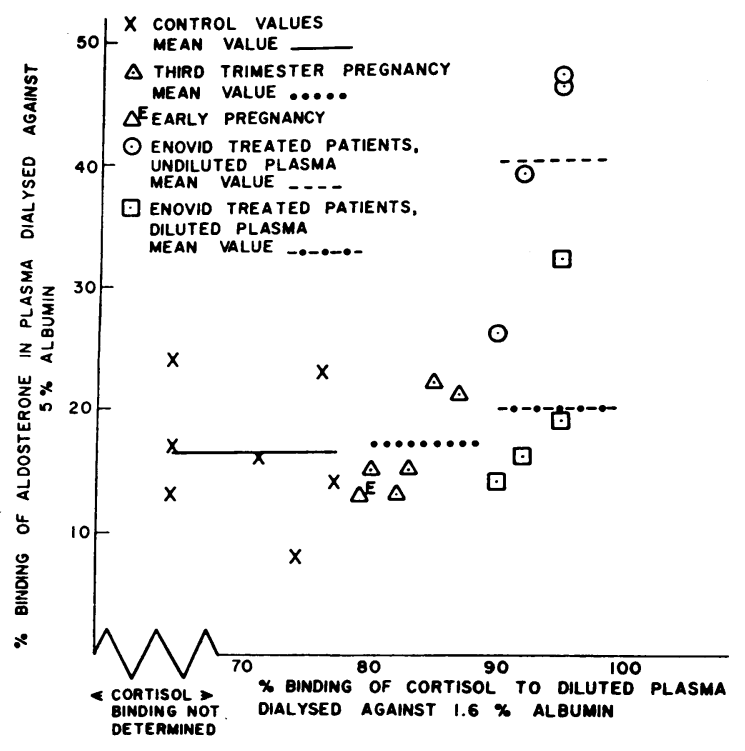

Fig. 1. The Relationship BetweEn the RELAtive BINDING OF ALDOSTERONE IN UNDILUTED PLASMA (ON THE ORDINATE) TO THAT OF CORTISOL IN PLASMA DILUTED $1: 3$ (ON THE ABSCISSAE) FROM NORMAL, PREGNANT AND ENOVID-TREATED WOMEN. All dialyses were performed with equal concentrations of albumin in the inner and outer chambers of the dialysis cell, except for points marked $\square$. These points show the relationship between the binding of aldosterone in 1:3 diluted plasma from Enovid-treated women, dialyzed against three times its concentration of albumin, to the binding of cortisol in the same plasma dialyzed against an equal concentration of albumin. 
Relative binding of aldosterone to plasma of patients treated with Enovid. In Enovid-treated patients the capacity of the plasma to bind cortisol is increased even more than in pregnancy, while the aldosterone relative binding in these patients was increased above normal under all conditions of dialysis (Table II, Figure 1). When diluted plasma was dialyzed against 1.6 per cent albumin the per cent binding was $31 \pm 7$ (SE). In undiluted plasma dialyzed against 5 per cent albumin the value was $40 \pm 5$ as compared with values of $16.4 \pm 2.2$ and $17 \pm 1.7$ in normal and pregnancy plasmas, respectively.

The albumin concentrations in the plasma of Enovid-treated patients, while not so low as those in pregnancy plasma, were lower than those in normal plasma, so that the increased binding cannot be due to larger albumin concentration in the inner chamber. This is further shown by the per cent binding of $20 \pm 4$ in diluted plasma (containing about 1.5 per cent albumin) dialyzed against 5 per cent albumin (Table II). The binding of aldosterone at $4^{\circ} \mathrm{C}$ in undiluted plasma dialyzed against physiological saline was over 90 per cent, as shown in Table V.

Table $\mathrm{V}$ also shows the per cent binding of aldosterone to diluted and undiluted plasma from Enovid-treated subjects after dialysis against 5 per cent albumin and against saline in both cases. An excellent correlation was found between the per cent binding of cortisol to diluted plasma (dialyzed against 1.6 per cent albumin) and aldosterone to undiluted plasma (dialyzed against 5 per cent albumin) in normal, pregnant, and Enovid-treated subjects (Figure 1). This correlation remained good even when the results for aldosterone relative binding in diluted plasma (containing about 1.6 per cent albumin) dialyzed against 5 per cent albumin were plotted against the results for cortisol binding in diluted plasma dialyzed against 1.6 per cent albumin. These results are shown in Figure 1 for Enovid-treated patients.

In confirmation of the results of Sandberg and co-workers (9), obtained at $4^{\circ} \mathrm{C}$, it was found that $1.0 \mu \mathrm{g}$ of aldosterone did not appreciably reduce the binding of cortisol in a normal plasma at $37^{\circ} \mathrm{C}$ (76 per cent), while 2,5 , and $10 \mu \mathrm{g}$ of aldosterone reduced this binding to 68,56 , and 48 per cent, respectively. Similar amounts of cortisol
TABLE V

Per cent binding of $\mathrm{H}^{3}$-aldosterone to plasma of Envoidtreated patients at $36^{\circ}$ and at $4^{\circ} C$; dialysis against albumin and against saline

\begin{tabular}{|c|c|c|c|c|}
\hline $\begin{array}{l}\text { Inner chamber } \\
\text { Plasma, } m l \\
\text { Saline, } m l\end{array}$ & $\begin{array}{l}1 \\
2 \\
507 \quad \text { lhumin }\end{array}$ & $\begin{array}{c}1 \\
2 \\
\text { Saline }\end{array}$ & 507 Alhumin & 3 \\
\hline Outer chamber & $\begin{array}{l}5 \% \text { Albumin } \\
1 \mathrm{~m} \mu \mathrm{g} \mathrm{H} \mathrm{H}^{3} \\
\text { aldosterone }\end{array}$ & $\begin{array}{l}\text { Saline } \\
1 \mathrm{~m} \mu \mathrm{g} \mathrm{H} \mathrm{H}^{3}- \\
\text { aldosterone }\end{array}$ & $\begin{array}{l}5 \% \text { Albumin } \\
3 \mathrm{~m} \mu \mathrm{g} \mathrm{H} \mathrm{H}^{3}- \\
\text { aldosterone }\end{array}$ & $\begin{array}{l}\text { Saline } \\
3 \mathrm{~m} \mu \mathrm{g} \mathrm{H} \mathrm{H}^{3}- \\
\text { aldosterone }\end{array}$ \\
\hline $37^{\circ}$ & 30 & 48 & 44 & 70 \\
\hline $4^{\circ}$ & 92 & 93 & 95 & 98 \\
\hline
\end{tabular}

consistently produced much greater reduction in the percentage binding of $7-\mathrm{H}^{3}$-cortisol to normal plasma at $37^{\circ} \mathrm{C}$. However, the binding of aldosterone to the plasma of an Enovid-treated patient (38 per cent) was not affected by the addition of $2 \mu \mathrm{g}$ of cortisol but was reduced to 30,19 , and 15 per cent when 5,10 , and $20 \mu \mathrm{g}$ of cortisol, respectively, were added to the plasma.

\section{DISCUSSION}

The above results provide strong evidence that there is a significant binding of aldosterone to a protein or proteins other than albumin in human plasma. The results are in agreement, qualitatively at least, with those of Sandberg and colleagues (9) and the Daughaday group (10). The latter found no binding of aldosterone to proteins other than albumin in normal, pregnant or estrogen-treated subjects at $37^{\circ} \mathrm{C}$, although they reported a binding at $4^{\circ} \mathrm{C}$. In the present experiments we found a definite binding of aldosterone to plasma proteins other than albumin in control and pregnant subjects at $37^{\circ} \mathrm{C}$. This binding was increased by treatment with Enovid, and in control plasma the binding of aldosterone was very much increased by lowering the temperature to $4^{\circ} \mathrm{C}$. The slight discrepancy between our results and those of Daughaday and co-workers could be explained by differences in the sensitivity of the methods used. In our studies the binding of aldosterone in normal subjects at $37^{\circ} \mathrm{C}$, while significant, was small, and it is possible that the method of the Daughaday group did not detect this binding; their result, a lowering of aldosterone binding at $37^{\circ} \mathrm{C}$ from 63 to 58 per cent on addition of cortisol, also indicates this possibility.

The nature of the proteins binding aldosterone has not been defined in these studies. In normal 
plasma the capacity of the protein for steroid is much higher than is the normal plasma concentration of aldosterone ( $1 \mathrm{~m} \mu \mathrm{g}$ per $3 \mathrm{ml}$ plasma) since $3,000 \mathrm{~m} \mu \mathrm{g}$ of aldosterone had to be added to $3 \mathrm{ml}$ of plasma to produce an appreciable lowering of the percentage binding, and even this is probably not a significant effect. This concentration (minimum after equilibrium, $1 \mu \mathrm{g}$ per $\mathrm{ml}$ ) approaches the amount of steroid needed to lower the binding of cortisol under similar conditions and suggests that the protein binding aldosterone may be transcortin. This conclusion is supported by the results in Enovid-treated patients in whom both cortisol and aldosterone binding was increased, and a good correlation was observed between these increases. The reduction of cortisol binding by aldosterone (although not so great as that produced by a similar amount of cortisol) is further evidence that aldosterone and cortisol are bound to the same protein, which has a greater affinity for cortisol than for aldosterone. In pregnancy, however, cortisol binding increases while that of aldosterone does not, suggesting that the protein binding aldosterone is not necessarily transcortin. Sandberg and colleagues (9) have shown in normal plasma at $4^{\circ} \mathrm{C}$ that the binding of aldosterone is rapidly reduced by the addition of cortisol, but we have found that the addition of cortisol, in amounts similar to that present in pregnancy plasma, has no effect on the binding of aldosterone at $37^{\circ} \mathrm{C}$ in Enovid-treated patients. It seems unlikely, therefore, that the high plasma cortisol levels present in pregnancy account for the failure to demonstrate increased binding of aldosterone in pregnancy plasma. It is possible that the presence of steroids other than cortisol may affect the binding of aldosterone, but protein fractionation studies on the plasma will be necessary before further conclusions can be drawn.

The physiological significance of the present in vitro results can only be clarified by the investigation in pregnant and Enovid-treated patients of in vivo phenomena that might be correlated with changes in plasma binding of aldosterone, such as the volumes of distribution and turnover rate of the hormone. Methods for the determination of these values have recently been devised, and it has been found that in normal subjects injected aldosterone spreads rapidly into an initial volume of $25 \mathrm{~L}$ and more slowly to $40 \mathrm{~L}$ (18). These vol- umes of distribution are much larger than those reported for cortisol (19), and the turnover rate of aldosterone is much greater than that of cortisol (18). One reason for this difference in the distribution and turnover rates of the steroids could be the much stronger binding of cortisol to plasma proteins. A situation analogous to that between cortisol and aldosterone has been noted in studies of the binding and transport of triiodothyronine and thyroxine (20). An increased binding of aldosterone in plasma would therefore be expected to decrease the volume of distribution and the turnover rate of the steroid. From the results of the present study no alteration in these values would be expected in pregnant as compared with normal subjects. Jones and co-workers (21) found no alteration in the urinary excretion of the free aldosterone expressed as a percentage of the secretion rate during pregnancy and, assuming this parameter to reflect the ratio of the blood concentration of the hormone to the secretion rate, they suggested that the turnover rate of aldosterone is probably the same in pregnant and normal subjects. Actual determination of the turnover rate and volume of distribution of injected $7-\mathrm{H}^{3}$-aldosterone in four women in the third trimester of pregnancy has shown no significant change in these values as compared with normal subjects (22). In the case of Enovidtreated subjects a decrease in the turnover rate would be expected from the increased binding found in the present experiments. This has not as yet been investigated.

The mechanism of action of Enovid in increasing the binding of aldosterone and cortisol in plasma will be the object of further studies. It is not known whether this activity is correlated with its estrogenic or progestogenic potency. The major point of the present studies was to demonstrate for the first time that under certain conditions the binding of aldosterone could be increased, and that this effect was correlated with increases in transcortin activity.

\section{SUMMARY}

The binding of $7-\mathrm{H}^{3}$-aldosterone to proteins in human plasma has been investigated by a microdialysis technique. The percentage relative binding of physiological amounts of aldosterone to 
undiluted plasma of normal women after dialysis against 5 per cent human serum albumin was $16.4 \pm 2.2$ (SE). Corresponding values for late pregnancy plasma were $17 \pm 1.7$, and for women treated with Enovid the percentage relative binding was $40 \pm 5$. These values are much smaller than those obtained for the percentage binding of cortisol to plasmas obtained from the same subjects.

It has also been found that aldosterone and cortisol are bound to albumin to about the same extent. However, dialysis of $7-\mathrm{H}^{3}$-aldosterone at $37^{\circ}$ and at $4^{\circ} \mathrm{C}$ against different concentrations of albumin provided evidence that the binding obtained in plasma dialyzed against albumin was not due to differences in the concentration of albumin in the plasma and in the outer dialysis chamber. Similar experiments with labeled estrone confirmed this conclusion.

The results are therefore interpreted as strong evidence that there is significant binding of aldosterone in human plasma to a protein or proteins other than albumin. Any increase of this binding during pregnancy is probably small, but there is a marked increase in relative binding after treatment with Enovid.

\section{ADDENDUM}

In five subjects treated with $0.3 \mathrm{mg}$ per day of ethinylestradiol 3-methyl ether the mean percentage binding of cortisol and of aldosterone was 89 and 38 per cent, respectively. These values resemble those obtained with a dose of $10 \mathrm{mg}$ per day of Enovid. Three patients on $0.1 \mathrm{mg}$ per day of ethinylestradiol 3-methyl ether showed no increase in relative binding of aldosterone. These results indicate that the increased binding of aldosterone caused by Enovid is probably due to its estrogenic potency. The authors incline to the conclusion that the effective estrogen levels in the pregnant subjects did not reach the threshold needed to raise the plasma binding of aldosterone.

\section{ACKNOWLEDGMENT}

We are indebted to Dr. Pedro Garcia and Dr. Brian Little for obtaining the plasma samples; to Mrs. L. E. Cushman for supervision of the patients, and to $\mathrm{Mr}$. Louis E. Bellaud for technical assistance.

\section{REFERENCES}

1. Daughaday, W. H. Evidence for two corticosteroid binding systems in human plasma (abstract). J. Lab. clin. Med. 1956, 48, 799.
2. Daughaday, W. H. Binding of corticosteroids by plasma proteins. V. Corticosteroid-binding globulin activity in normal human beings and in certain disease states. A.M.A. Arch. intern. Med. 1958, 101, 286.

3. Slaunwhite, W. R., Jr., and Sandberg, A. A. Transcortin: A corticosteroid binding protein of plasma. J. clin. Invest. 1959, 38, 384.

4. Sandberg, A. A., and Slaunwhite, W. R., Jr. Transcortin: A corticosteroid binding protein of plasma. II. Levels in various conditions and the effects of estrogens. J. clin. Invest. 1959, 38, 1290.

5. Bush, I. E. The physicochemical state of cortisol in blood. Ciba Found. Coll. Endocr. 1957, 11, 263.

6. Upton, G. V., and Bondy, P. K. The binding of cortisol by plasma protein. Arch. Biochem. 1958, 78, 197.

7. Mills, I. H., Chen, P. S., and Bartter, F. C. The protein-binding of steroids as studied by ultrafiltration (abstract). J. Endocr. 1959, 18, xxx.

8. Mills, I. H., Chen, P. S., Jr., and Bartter, F. C. Private communication. 1960.

9. Sandberg, A. A., Slaunwhite, W. R., Jr., and Carter, A. C. Transcortin: A corticosteroid binding protein of plasma. III. The effects of various steroids. J. clin. Invest. 1960, 39, 1914.

10. Daughaday, W. H., Holloszy, J., and Mariz, I. K. Binding of corticosteroids by plasma proteins. VI. The binding of cortisol and aldosterone by corticosteroid-binding globulin and by the estrogen-induced binding system of plasma. J. clin. Endocr. 1961, 29, 53.

11. Kalant, H. A microdialysis procedure for extraction and isolation of corticosteroids from peripheral blood plasma. Biochem. J. 1958, 69, 99.

12. Ayres, P. J., Pearlman, W. H., Tait, J. F., and Tait, S. A. S. The biosynthetic preparation of $[16-3 \mathrm{H}]$ aldosterone and $[16-3 \mathrm{H}]$ corticosterone. Biochem. J. 1958, 70, 230.

13. Rutstein, D. D., Ingenito, E. F., and Reynolds, W. E. The determination of albumin in human blood plasma and serum. A method based on the interaction of albumin with an anionic dye-2- $\left(4^{\prime}\right.$ hydroxybenzeneazo) benzoic acid. J. clin. Invest. 1954, 33, 211.

14. Hayes, F. N., and Gould, R. G. Liquid scintillation counting of tritium-labeled water and organic compounds. Science 1953, 117, 480.

15. Simpson, S. A., and Tait, J. F. The possible role of electrocortin in normal human metabolism. Ciba Found. Coll. Endocr. 1955, 8, 204.

16. Longworth, L. G., Curtis, R. M., and Pembroke, R. H., Jr. The electrophoretic analysis of maternal and fetal plasmas and sera. J. clin. Invest. 1955, 24, 46.

17. Dowling, J. T., Freinkel, N., and Ingbar, S. H. Thyroxine-binding by sera of pregnant women, newborn infants, and women with spontaneous abortion. J. clin. Invest. 1956, 35, 1263. 
18. Tait, J. F., Tait, S. A. S., Little, B., and Laumas, K. R. The disappearance of $7-\mathrm{H}^{3}-d$-aldosterone in the plasma of normal subjects. $\mathrm{J}$. clin. Invest. 1961, 40, 72.

19. Peterson, R. E. The miscible pool and turnover rate of adrenocortical steroids in man. Recent Progr. Hormone Res. 1959, 15, 231.

20. Pitt-Rivers, R., and Tata, J. R. The Thyroid Hormones. London, Pergamon Press, 1959, p. 133.
21. Jones, K. M., Lloyd-Jones, R., Riondel, A., Tait, J. F., Tait, S. A. S., Bulbrook, R. D., and Greenwood, F. A. Aldosterone secretion and metabolism in normal men and women and in pregnancy. Acta Endocr. (Kbh.) 1959, 30, 321.

22. Layne, D. S., Little, B., Meyer, C. J., Tait, J. F., and Tait, S. A. S. The turnover rate, distribution, and plasma binding of aldosterone in pregnancy. Proc. Forty-third Meeting of the Endocrine Society. New York, 1961, p. 16. 